\title{
Post-genomic analyses of fungal lignocellulosic biomass degradation reveal the unexpected potential of the plant pathogen Ustilago maydis
}

\author{
Marie Couturier ${ }^{1}$, David Navarro ${ }^{1,2}$, Caroline Olivé ${ }^{1}$, Didier Chevret $^{3}$, Mireille Haon ${ }^{1,2}$, Anne Favel ${ }^{1,2,4}$, \\ Laurence Lesage-Meessen ${ }^{1,2}$, Bernard Henrissat ${ }^{5}$, Pedro M Coutinho ${ }^{4,5}$ and Jean-Guy Berrin ${ }^{1 *}$
}

\begin{abstract}
Background: Filamentous fungi are potent biomass degraders due to their ability to thrive in ligno(hemi)celluloserich environments. During the last decade, fungal genome sequencing initiatives have yielded abundant information on the genes that are putatively involved in lignocellulose degradation. At present, additional experimental studies are essential to provide insights into the fungal secreted enzymatic pools involved in lignocellulose degradation.

Results: In this study, we performed a wide analysis of 20 filamentous fungi for which genomic data are available to investigate their biomass-hydrolysis potential. A comparison of fungal genomes and secretomes using enzyme activity profiling revealed discrepancies in carbohydrate active enzymes (CAZymes) sets dedicated to plant cell wall. Investigation of the contribution made by each secretome to the saccharification of wheat straw demonstrated that most of them individually supplemented the industrial Trichoderma reesei CL847 enzymatic cocktail. Unexpectedly, the most striking effect was obtained with the phytopathogen Ustilago maydis that improved the release of total sugars by $57 \%$ and of glucose by $22 \%$. Proteomic analyses of the best-performing secretomes indicated a specific enzymatic mechanism of $U$. maydis that is likely to involve oxido-reductases and hemicellulases.

Conclusion: This study provides insight into the lignocellulose-degradation mechanisms by filamentous fungi and allows for the identification of a number of enzymes that are potentially useful to further improve the industrial lignocellulose bioconversion process.
\end{abstract}

Keywords: Filamentous fungi, genomes, lignocellulose, enzymatic hydrolysis, cellulases, oxido-reductases, glycosyl hydrolases, Ustilago maydis, mass spectrometry

\section{Background}

Lignocellulosic biomass conversion to simple sugars is widely studied for subsequent fermentation to bioethanol or industrial chemicals but biotechnological processes are both complex and costly [1,2]. In the biorefinery process, enzymatic hydrolysis (i.e. saccharification) is one of the major bottlenecks due to the recalcitrance of plant cell wall whose main components, cellulose, hemicellulose and lignin form a tight complex with varying proportions depending on plant species $[3,4]$.

\footnotetext{
* Correspondence: jean-guy.berrin@univmed.fr

'INRA, UMR1163 BCF, 13288 Marseille, France

Full list of author information is available at the end of the article
}

Filamentous fungi are among the most potent degraders of lignocellulosic biomass as they produce a high number and a broad variety of enzymes that have different and complementary catalytic activities [5]. The degradation of lignocellulose by filamentous fungi has been studied in a range of basidiomycetes and ascomycetes. Among wood-decaying basidiomycetes, the whiterot fungi Phanerochaete chrysosporium [6] is known to secrete a wide range of enzymes such as lignin peroxidases and glycosyl hydrolases (GHs) [7]. Many ascomycetes species have been identified as good candidates for the release of monosaccharides such as Trichoderma reesei, which is used extensively in industry due to its capacity to secrete high level of cellulases. T. reesei has
C Biomed Central

() 2012 Couturier et al; licensee BioMed Central Ltd. This is an Open Access article distributed under the terms of the Creative Commons Attribution License (http://creativecommons.org/licenses/by/2.0), which permits unrestricted use, distribution, and reproduction in any medium, provided the original work is properly cited. 
undergone several rounds of mutation/selection starting from the QM6a strain. As a result, the engineered T. reesei industrial strain CL847 is able to secrete more than $50 \mathrm{~g}$ of proteins per litre of culture, which permits a wide-range of applications in different fields of white biotechnology. Additional genetic and biochemical studies have deeply improved our knowledge of $T$. reesei enzymes. More recently, the release of the $T$. reesei genome (QM6a strain) has shown that its carbohydrate active enzyme (CAZyme) machinery is globally comparable to other saprophytic fungi [8-10]. However, compared to other filamentous fungi, the $T$. reesei genome is poor in terms of number and diversity of enzymes that are likely to be involved in biomass degradation [8]. The lack of key lignocellulosic enzymes in $T$. reesei opens opportunities to generate more competitive enzyme cocktails.

During the last decade, large efforts have been concentrated on genome sequencing of ascomycetes, and only a few basidiomycetes genomes were made available. The genomes of phytopathogenic fungi such as Fusarium graminearum, a wheat pathogen [11], and Ustilago maydis, a maize pathogen [12], have been published. Saprotrophic fungi have also been targeted, e.g., the basidiomycete $P$. chrysosporium [6], the ascomycetes Neurospora crassa, Nectria haematococca [13,14] and several Aspergilli, such as Aspergillus nidulans, Aspergillus fumigatus, Aspergillus oryzae and Aspergillus niger [15-18]. Several other Aspergillus genomes (Aspergillus clavatus, Aspergillus fischeri, Aspergillus flavus and Aspergillus terreus) have now also been sequenced, and the list continues to grow $[19,20]$.

Although in silico annotations of fungal genomes provides large amounts of information about the genes that encode putative lignocellulose-degrading enzymes, experimental analyses are necessary to better understand complex mixture of enzymes that are secreted (i.e. the secretome) in response to inducers. In this study, we thus characterised 20 fungal species for which genomic data are available for their ability to secrete CAZymes targeting plant cell wall by means of high-throughput enzymatic assays and proteomic analyses.

\section{Results and Discussion}

Genomic analysis of the fungal CAZyme sets dedicated to the plant cell wall

To determine the sugar-cleaving capabilities of the fungi selected (Table 1), we compared their CAZyme repertoires ( $\mathrm{GH}$ and polysaccharide lyases, PL) (Figure $1)$. Clustering of the CAZyme repertoires and the selected fungi resulted in the formation of clusters of fungal species that corresponded with their fungal phyla. As expected, the Aspergilli and Fusaria species have relatively high numbers of $\mathrm{GH}$-encoding genes. In contrast, the $U$. maydis and the zygomycetes Phycomyces blakesleeanus and Rhizopus oryzae genomes had relatively few genes that encoded for GH. These results indicate different strategies to degrade plant cell wall. The only exception was $A$. clavatus which was grouped with $N$. crassa and Chaetomium globosum, both members of the Sordariales order. Interestingly, these three species all share a common feature, as they are known to act on recalcitrant plant material (i.e. are coprophilic).

\section{Saccharification efficiencies of fungal secretomes}

Hydrolysis of plant biomass requires the production of many different enzymes, which is regulated by the type and complexity of the plant material used as an inducer for the fungal cultures. For example, it has been shown that Aspergillus secretomes are strongly tied to the culture conditions and the nutrient sources available [21]. In this study, maize bran was selected as an inducer because (i) it is a natural substrate, (ii) it has been described as being fairly complex and recalcitrant with arabinose and ferulic acid substitutions [22] and (iii) it is a powerful inducer for the expression of a broad range of genes that encode for CAZymes targeting the plant cell wall, e.g., endo-xylanase, endo-mannanase, arabinofuranosidase and carbohydrate esterases [22-24]. All the fungi tested were able to grow on maize bran with a satisfactory yield of secreted protein and were harvested at a single time point, i.e. 7 days of growth (see materials and methods).

Each secretome was diafiltered and concentrated and then tested for its ability to release sugars from micronised wheat straw (WS), taking advantage of the recently developed automated saccharification method [25]. The release of reducing sugars and individual sugar monomers was quantified at the initial rate of hydrolysis $(4 \mathrm{~h})$ and at the saccharification plateau $(24 \mathrm{~h})$, the $T$. reesei CL847 enzymatic cocktail being used as reference (Table 2).

To evaluate the contribution of each secretome to the initial rate of the reaction compared to the $T$. reesei CL847 enzyme cocktail alone, supplementation experiments were performed using the same amount of total enzyme loading (Table 2). As a result, seven secretomes increased significantly the initial rate of the release of reducing sugars. Among them, four secretomes ( $A$. niger, A. flavus, A. fumigatus and A. nidulans) were able to increase the glucose rate compared to the $T$. reese $i$ CL847 enzyme cocktail alone. The most striking effects were obtained with $A$. nidulans and $A$. niger, which increased the glucose rate by 1.6 - and 1.9-fold, respectively, compared to $T$. reesei CL847.

At the saccharification plateau, each secretome was tested alone and in combination with T. reesei CL847 
Table 1 Description of strains used in this study.

\begin{tabular}{|c|c|c|c|c|c|c|}
\hline & $\begin{array}{l}\text { Species } \\
\text { anamorph (teleomorph*) }\end{array}$ & Phylum & Family & Original number & Strain ref number & CIRM number \\
\hline T.rees. & Trichoderma reesei (Hypocrea jecorina) & Ascomycota & Hypocreaceae & QM6a & CBS 383.78 & BRFM 1104 \\
\hline P.blak. & Phycomyces blakesleeanus & Zygomycota & Phycomycetaceae & NRRL 1555 & FGSC 10004 & BRFM 1098 \\
\hline R.oryz. & Rhizopus oryzae (R. arrhizus) & Zygomycota & Mucoraceae & RA 99-880 & FGSC 9543 & BRFM 1095 \\
\hline M.circ. & Mucor circinelloides f lusitanicus & Zygomycota & Mucoraceae & NRRL 3631 & CBS 277.49 & BRFM 1099 \\
\hline U. may. & Ustilago maydis & Basidiomycota & Ustilaginaceae & UM521 & FGSC 9021 & BRFM 1093 \\
\hline P.chry. & Phanerochaete chrysosporium & Basidiomycota & Phanerochaetaceae & $\mathrm{RP} 78$ & FGSC 9002 & BRFM 1090 \\
\hline T. stip. & Penicillium emmonsii (Talaromyces stipitatus) & Ascomycota & Trichocomaceae & NRRL 1006 & CBS 375.48 & BRFM 1102 \\
\hline A.fisc. & Aspergillus fischeri (Neosartorya fischeri) & Ascomycota & Trichocomaceae & NRRL 181 & CBS 544.65 & BRFM 1101 \\
\hline A.nig. & Aspergillus niger & Ascomycota & Trichocomaceae & ATCC 1015 & FGSC A1144 & BRFM 1087 \\
\hline A.ter. & Aspergillus terreus & Ascomycota & Trichocomaceae & $\mathrm{NIH} 2624$ & FGSC A1156 & BRFM 1088 \\
\hline A.flav. & Aspergillus flavus & Ascomycota & Trichocomaceae & NRRL 3357 & FGSC A1120 & BRFM 1086 \\
\hline A.clav. & Aspergillus clavatus & Ascomycota & Trichocomaceae & NRRL 1 & CBS 513.65 & BRFM 1100 \\
\hline A.fumi. & Aspergillus fumigatus & Ascomycota & Trichocomaceae & AF 293 & FGSC A1100 & BRFM 1085 \\
\hline A.nid. & Aspergillus nidulans (Emericella nidulans) & Ascomycota & Trichocomaceae & M 139 & FGSC A4 & BRFM 1084 \\
\hline F.oxy. & Fusarium oxysporum f lycopersici & Ascomycota & Nectriaceae & NRRL 34936 & FGSC 9935 & BRFM 1097 \\
\hline N.haem. & Fusarium solani (Nectria haematococca) & Ascomycota & Nectriaceae & $77-13-4$ & FGSC 9596 & BRFM 1096 \\
\hline F.gra. & Fusarium graminearum (Gibberella zeae) & Ascomycota & Nectriaceae & NRRL 31084 & FGSC 9075 & BRFM 1094 \\
\hline F. ver. & Fusarium verticillioides (Gibberella moniliformis) & Ascomycota & Nectriaceae & A-00149 & FGSC 7600 & BRFM 1089 \\
\hline C.glob. & Chaetomium globosum & Ascomycota & Chaetomiaceae & NRRL1870 & CBS 148.51 & BRFM 1103 \\
\hline N.cras. & Neurospora crassa & Ascomycota & Sordariaceae & OR74A & FGSC 9013 & BRFM 1092 \\
\hline
\end{tabular}

${ }^{*}$ when available, ${ }^{* *}$ industrial enzymatic cocktail $T$. reesei CL847

enzyme cocktail. As expected, the improved T. reesei CL847 enzyme cocktail released more reducing sugars from WS than the secretome of the T. reesei QM6a strain. The glucose and xylose yields were 2.8- and 1.3-fold higher with the T. reesei CL847 cocktail than those obtained with the QM6a secretome. The most efficient secretomes, when used alone on micronised WS, were A. nidulans, Talaromyces stipitatus and $U$. maydis secretomes, which yielded higher amounts of reducing sugars compared to $T$. reesei CL847 (Table 2 ). This observation is in agreement with the quantification of the monomers that showed differences in sugar release, i.e., $A$. nidulans and $U$. maydis yielded primarily glucose, whereas $T$. stipitatus yielded mainly xylose. The supplementation of $T$. reesei CL847 with most of the fungal secretomes resulted in a significant increase in the release of soluble sugars, up to a 1.6fold increase when compared to $T$. reesei alone. A closer look at the monomers indicated that five of the secretomes ( $U$. maydis, T. stipitatus, A. fischeri, A. fumigatus and $A$. nidulans) displayed a significant positive effect on both the release of glucose and xylose, while P. blakesleeanus only increased the release of xylose. The strongest effect on the release of glucose in the supplementation experiments was obtained when $U$. maydis and $A$. nidulans secretomes were used; they improved the $T$. reesei CL847 enzymatic cocktail by more than $20 \%$ (Table 2 ).

\section{Enzymatic characterisation of the fungal secretomes using activity profiling}

To assess the sugar-cleaving capabilities of all of the fungal secretomes, we quantified their main glycosidehydrolase activities using a microplate assay that contained para-nitrophenyl ( $p \mathrm{NP})$-sugars and complex polysaccharides as substrates (See additional file 1, Table $\mathrm{S} 1$ ). Cellulose degradation was estimated by the quantification of endo-glucanase (carboxy-methyl cellulose, CMC), Avicelase (Avicel, AVI), FPase (Filter paper, FP), cellobiohydrolase ( $p \mathrm{NP}-\beta$-D-cellobioside, $\mathrm{pCel}$ and $p \mathrm{NP}$ $\beta$-D-lactobioside, $\mathrm{pLac}$ ) and $\beta$-glucosidase ( $p \mathrm{NP}-\beta$-Dglucopyranoside, pGlc) activities. Hemicellulose degradation was estimated by quantifying the xylanases and mannanases using structurally different xylans and mannans as substrates. The main exo-acting glycosidases activities were estimated by the quantification of $p \mathrm{NP}$ $\alpha$-L-arabinofuranoside (pAra), $p \mathrm{NP}-\alpha-\mathrm{D}$-galactopyranoside (pGal), $p$ NP- $\beta$-D-xylopyranoside (pXyl) and $p$ NP- $\beta$ $\mathrm{D}$-mannopyranoside (pMan). Pectic degradation was assessed using arabinogalactan (AGA) and arabinan (ARB) and the overall esterase activity was assessed using $p \mathrm{NP}$-acetate (pAc).

Comparison of the $T$. reesei CL847 industrial cocktail with the original T. reesei QM6a strain used for genome sequencing revealed (i) a similar cellobiohydrolase and FPase activity, (ii) a 10-fold increase in the endo-glucanase and $\beta$-glucosidase activities and (iii) a significant 


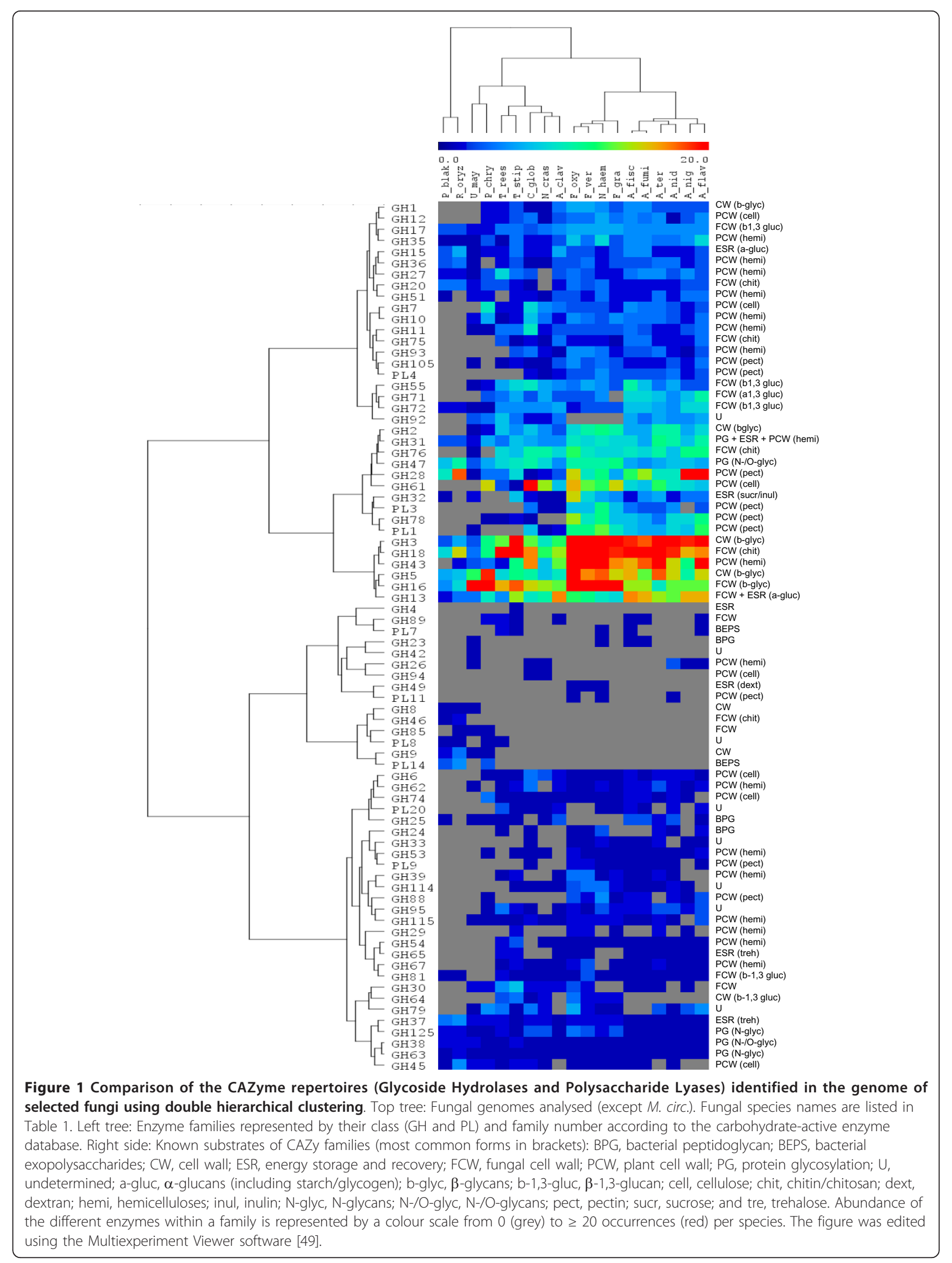


Table 2 Contribution of fungal secretomes to the saccharification of wheat straw.

\begin{tabular}{|c|c|c|c|c|c|c|c|c|c|c|c|c|c|c|c|c|c|c|c|c|c|c|}
\hline & & $\begin{array}{l}\text { T. rees. } \\
\text { CL847 }\end{array}$ & $\begin{array}{l}\text { T. rees. } \\
\text { QM6a }\end{array}$ & $\begin{array}{l}P . \\
\text { blak. }\end{array}$ & $\begin{array}{l}R . \\
\text { oryz. }\end{array}$ & $\begin{array}{l}\text { M. } \\
\text { circ. }\end{array}$ & $\begin{array}{l}\text { P. } \\
\text { chry. }\end{array}$ & $\begin{array}{l}U . \\
\text { may. }\end{array}$ & $\begin{array}{l}T . \\
\text { stip. }\end{array}$ & $\begin{array}{l}\text { A. } \\
\text { fisc. }\end{array}$ & $\begin{array}{l}\text { A. } \\
\text { nig. }\end{array}$ & $\begin{array}{l}\text { A. } \\
\text { ter. }\end{array}$ & $\begin{array}{l}\text { A. } \\
\text { flav. }\end{array}$ & $\begin{array}{l}\text { A. } \\
\text { clav. }\end{array}$ & $\begin{array}{l}\text { A. } \\
\text { fumi. }\end{array}$ & $\begin{array}{l}\text { A. } \\
\text { nid. }\end{array}$ & $\begin{array}{l}F . \\
\text { oxy. }\end{array}$ & $\begin{array}{l}\text { N. } \\
\text { haem. }\end{array}$ & $\begin{array}{l}\text { F. } \\
\text { gram. }\end{array}$ & $\begin{array}{l}\text { F. } \\
\text { ver. }\end{array}$ & $\begin{array}{l}\text { C. } \\
\text { glob. }\end{array}$ & $\begin{array}{l}N . \\
\text { cras. }\end{array}$ \\
\hline \multicolumn{23}{|c|}{ Initial step (4 h) } \\
\hline \multirow[t]{2}{*}{$\stackrel{+}{\mathrm{CL} 847}$} & $\begin{array}{l}\text { DNS (glucose } \\
\text { equivalent) }\end{array}$ & 0.082 & 0.106 & 0.084 & 0.074 & 0.083 & 0.083 & 0.084 & 0.112 & 0.097 & 0.095 & 0.086 & 0.087 & 0.106 & 0.112 & 0.146 & 0.078 & 0.078 & 0.077 & 0.087 & 0.090 & 0.093 \\
\hline & glucose & 0.071 & 0.051 & 0.033 & 0.036 & 0.049 & 0.038 & 0.037 & 0.059 & 0.060 & 0.091 & 0.041 & 0.074 & 0.051 & 0.070 & 0.080 & 0.037 & 0.050 & 0.043 & 0.043 & 0.051 & 0.044 \\
\hline \multicolumn{23}{|c|}{ Plateau (24 h) } \\
\hline \multirow[t]{3}{*}{$\stackrel{-}{C L 847}$} & $\begin{array}{l}\text { DNS (glucose } \\
\text { equivalent) }\end{array}$ & 0.180 & 0.125 & 0.086 & 0.107 & 0.081 & 0.063 & 0.241 & 0.213 & 0.136 & 0.084 & 0.076 & 0.060 & 0.100 & 0.127 & 0.187 & 0.086 & 0.028 & 0.109 & 0.084 & 0.058 & 0.115 \\
\hline & glucose & 0.094 & 0.033 & 0.021 & 0.021 & 0.018 & 0.020 & 0.097 & 0.032 & 0.032 & 0.034 & 0.017 & 0.016 & 0.021 & 0.035 & 0.085 & 0.025 & 0.020 & 0.036 & 0.022 & 0.026 & 0.040 \\
\hline & xylose & 0.042 & 0.034 & 0.035 & 0.030 & 0.012 & 0.000 & 0.034 & 0.046 & 0.042 & 0.023 & 0.019 & 0.017 & 0.026 & 0.038 & 0.023 & 0.020 & 0.014 & 0.028 & 0.000 & 0.008 & 0.018 \\
\hline \multirow[t]{3}{*}{$\stackrel{+}{\mathrm{CL} 847}$} & $\begin{array}{l}\text { DNS (glucose } \\
\text { equivalent) }\end{array}$ & 0.181 & 0.216 & 0.208 & 0.209 & 0.211 & 0.202 & 0.285 & 0.222 & 0.246 & 0.222 & 0.208 & 0.213 & 0.227 & 0.248 & 0.287 & 0.213 & 0.246 & 0.222 & 0.208 & 0.180 & 0.216 \\
\hline & glucose & 0.094 & 0.088 & 0.091 & 0.083 & 0.083 & 0.078 & 0.115 & 0.103 & 0.105 & 0.095 & 0.085 & 0.081 & 0.089 & 0.100 & 0.119 & 0.093 & 0.094 & 0.092 & 0.085 & 0.079 & 0.089 \\
\hline & xylose & 0.043 & 0.041 & 0.053 & 0.035 & 0.034 & 0.031 & 0.055 & 0.048 & 0.053 & 0.041 & 0.034 & 0.034 & 0.038 & 0.047 & 0.052 & 0.036 & 0.045 & 0.040 & 0.030 & 0.032 & 0.039 \\
\hline
\end{tabular}

means of sextuplicate and triplicate measures, respectively. Standard errors of the mean were $<5 \%$. 
decrease in the xylanase activity (See additional file 1, Table S1). The A. niger secretome was, by far, the richest in terms of diversity of enzyme activities measured, except that a low activity towards AVI $(4 \mathrm{mU} / \mathrm{mg})$ was observed. AVI was better hydrolysed using the P. blakesleeanus, P. chrysosporium, F. graminearum and N. crassa secretomes. An overall comparison with the hydrolysis of CMC and FP did not show an obvious trend. For example, the $A$. nidulans secretome displayed an activity towards FP that was comparable with $T$. reesei CL847 and QM6a but was unable to hydrolyse CMC and AVI (See additional file 1, Table S1). With regard to hemicellulose degradation, most of the secretomes were able to significantly hydrolyse all of the tested xylans. Soluble wheat arabinoxylan (SAX) was better hydrolysed than birchwood xylan (BRX) and insoluble wheat arabinoxylan (IAX). The only exception was $A$. terreus, which preferred birchwood xylan. $R$. oryzae appeared to be unable to breakdown significant amount of xylan, as it was recently shown using a range of polysaccharides as carbon sources [26]. Analysis of the correlation between specific activities data and the enzyme composition of secretomes is relatively complicated due to the presence of multi-functional enzymes and synergistic interactions between enzymes [4,27].

In order to navigate in the data set and to evaluate the similarities and differences among its components, we performed a double hierarchical clustering (except for the $T$. reesei CL847 enzyme cocktail) with the same bioinformatics tools used to analyse the genomes (Figure 1). Analysis of the full data set identified clusters of strains that showed similar hydrolytic profiles and substrates clusters (Figure 2). A. niger was grouped in the cluster that displayed the highest level of activity towards plant cell wall polysaccharides along with four other Aspergilli (A. clavatus, A. fischeri, A. flavus and A. fumigatus), T. reesei QM6a, Mucor circinelloides and $T$. stipitatus. However, A. terreus and A. nidulans did not cluster with the other Aspergilli. A. nidulans shares traits in common with $C$. globosum and R. oryzae, i.e., a very low activity towards xylans. It is interesting to note that three out of the four Fusaria were clustered into the same group and that $P$. chrysosporium did not cluster with any of the other species. Based on data from the literature, wood material or AVI might have been more suitable inducers for $P$. chrysosporium than maize bran and allowed the secretion of a more complete array of plant cell wall degrading enzymes $[7,28,29]$. Both basidiomycetes $P$. chrysosporium and $U$. maydis activity profiles were rather atypical as they were not correlated together, neither with the other fungi (Figure 2).

When we clustered the substrates on the basis of the activity profiling data, we found that the three xylans tested (BRX, SWX and IWX) clustered together. The correlations observed between the activity on pGlc and pCel can be explained by the fact that both are substrates of $\beta$-glucosidases. Although the activity towards cellulosic substrates (CMC, AVI and FP) was not correlated, FP activity was associated with both xylan and WS hydrolysis. These data suggest that FP activity is a better marker than Avicelase activity to estimate the cellulose hydrolysis by fungal secretomes. P. blakesleeanus, T. stipitatus, A. fischeri, A. terreus, and A. fumigatus secretomes, which all displayed higher FP activities than T. reesei CL847 (See additional file 1, Table S1), did not release more glucose from WS (Table 2). Thus, FP activity is not the only factor governing the cellulose hydrolysis efficiency of fungal secretomes. Indeed, it was recently reported that proteins devoid of measurable activity (e.g. GH61) can significantly improve the activity of PCW-degrading enzymes [30,31].

\section{Proteomic analyses of the best performing fungal secretomes}

Recently, there has been growing interest for the detailed analysis of fungal secretomes [28,29,32-34]. Liquid chromatography-tandem mass spectrometry (LCMS/MS) proteomic analysis is a tool of great interest to attempt to make available the relative abundances of their different protein components. Based on saccharification data, the best-performing secretomes, i.e. $A$. niger, $A$. nidulans and $U$. maydis, were selected to be analysed in depth using 1D LC-MS/MS along with the T. reesei CL847 enzymatic cocktail. A. niger was further investigated due to its capacity to potentiate $T$. reese $i$ CL847 enzymatic cocktail activity at the initial step of hydrolysis whereas $A$. nidulans and $U$. maydis were selected for their boosting effect observed at the saccharification plateau.

Proteomic analysis of the T. reesei CL847 enzymatic cocktail allowed the identification of 32 proteins of which 27 were CAZymes targetting plant cell wall, e.g., CBHI (GH7) and CBHII (GH6)/EGI (GH7), EGII (GH5), EGIII (GH12), EGIV (GH61) and EGVI (GH74)/ BGLI (GH3)/XYNII (GH11) and XYNIII (GH10)/BXLI (GH3)/ABFI (GH54), ABFII (GH62) and ABFIII (GH54) (See additional file 2, Table S2). These results are in agreement with the proteomic analysis of $T$. reesei CL847 secretome using 2D gel that allowed the identification of 22 proteins [35]. It is interesting to note that our proteomic analysis of $T$. reesei CL847 enzymatic cocktail also showed that the proteins displaying a family 1 carbohydrate binding module (CBM) were among the most abundant protein of the enzymatic cocktail (See additional file 2, Table S2).

Concerning the fungal species selected for proteomic analysis, a total of 242,66 and 86 proteins were detected 


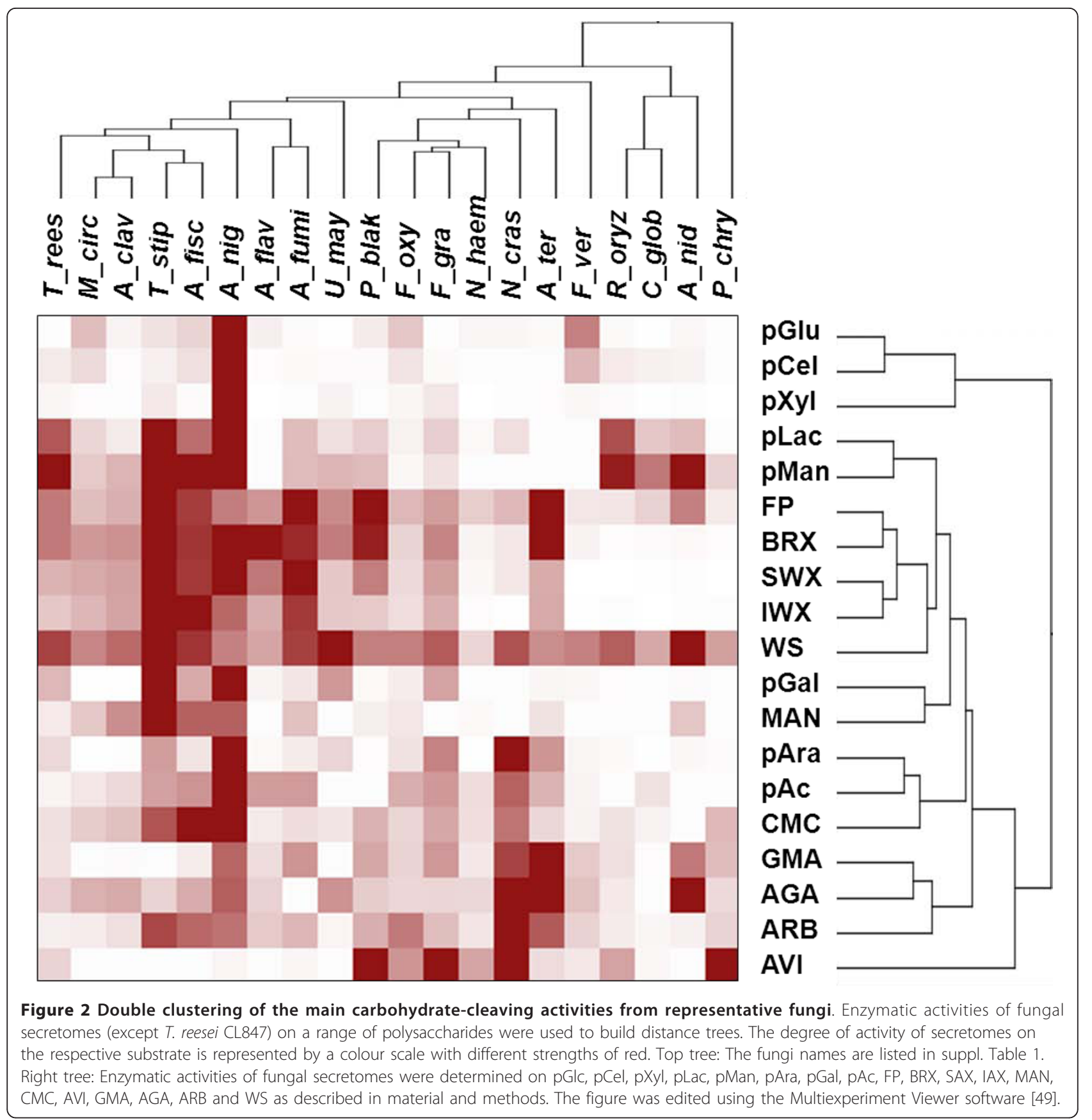

from the concentrated secretomes of $A$. niger, A. nidulans and $U$. maydis, respectively, by mass-matching against corresponding protein databases. The A. niger secretome contained an impressive array of 118 CAZymes out of the total 242 proteins (Figure 3). The number of exo-acting glycosidases identified in the secretome of $A$. niger when cultured in the presence of maize bran was disproportionally higher than the number of endo-acting CAZymes (See additional file 2, Table S2). This observation corresponds with a previous proteomic analysis on the $A$. niger secretome under different cultured environments [34]. The presence of a broad array of exo-acting glycosidases might be responsible for the significant increase in the initial rate of saccharification when the $A$. niger secretome was added to the T. reesei CL847 enzyme cocktail. Surprisingly, this positive effect was not observed at the saccharification plateau, indicating that the large diversity and high number of CAZymes do not act in concert with the $T$. reesei enzymes during the saccharification of WS. 


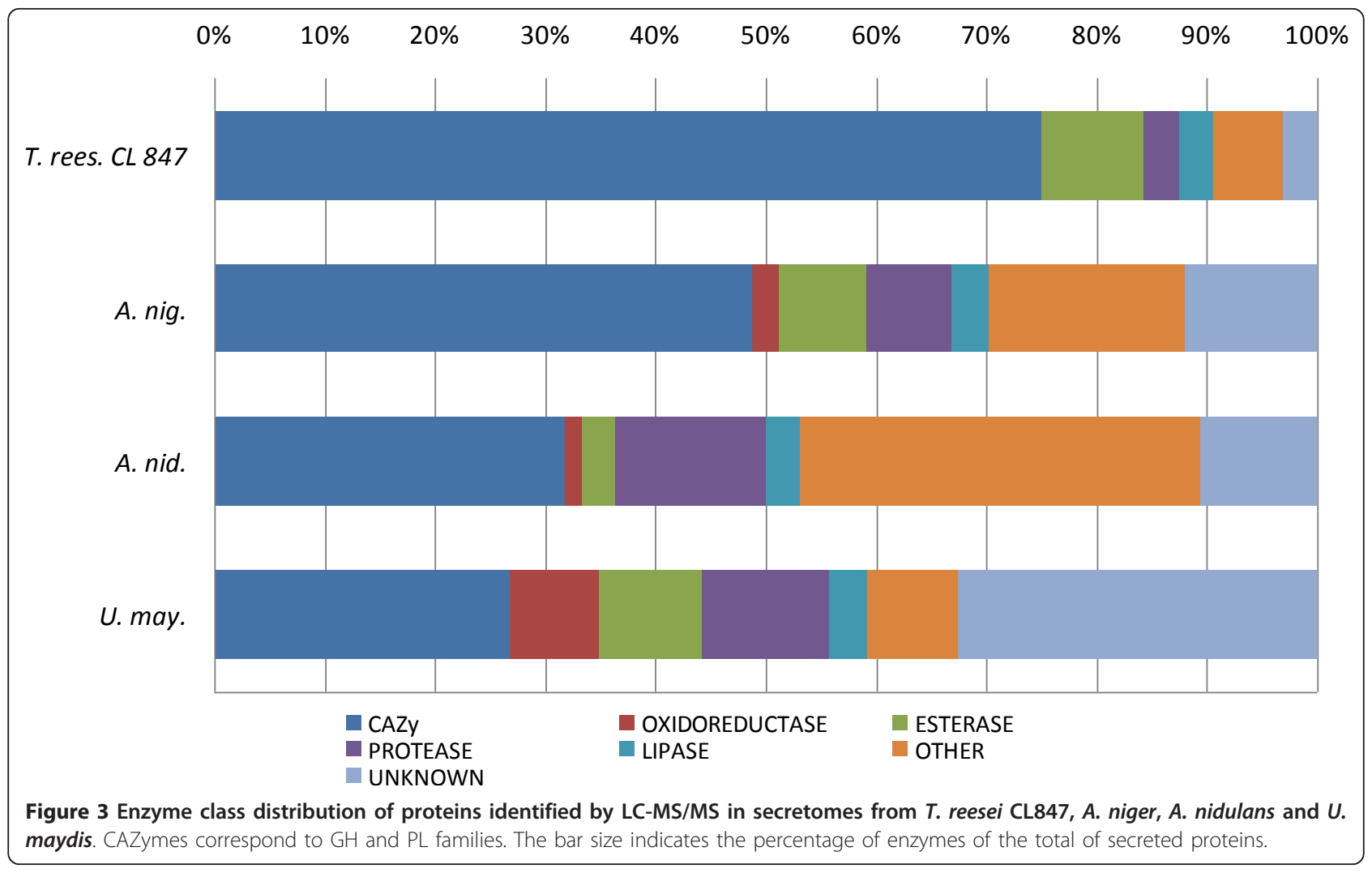

Compared to $A$. niger, the $A$. nidulans secretome displayed a lower enzymatic diversity towards plant cell walls. This striking difference could be due to the regulatory mechanisms of enzyme induction, which are controlled by the xylose and arabinose transcriptional activators $X \ln R$ and AraR that differ between A. nidulans and A. niger [19,36,37]. Of the 19 GHs identified in the $A$. nidulans secretome, we identified seven hemicellulases from the GH10, GH11, GH39, GH43, GH62 and GH93 families and five $\beta-1,3$ glucanases from the GH17, GH55 and GH81 families (See additional file 2, Table S2). The absence of activity on CMC and AVI correlated with the fact that no endo $\beta-1,4$ glucanase or cellobiohydrolase was identified by proteomics. However, the high activities of the $A$. nidulans secretome on FP and WS are rather intriguing (See Figure 2 and additional file 1, Table S1). This observation might suggest the presence of novel specificities among the plant cell wall degrading enzymes.

The analysis of $U$. maydis secretome revealed a total of 86 proteins (see additional file 2, Table S2). They represent more than half of the theoretically secreted proteins as $U$. maydis genome is supposed contains 168 genes that encode for secreted proteins [38]. The $U$. maydis genome contains one of the smallest sets of genes that encode for CAZymes with $95 \mathrm{GH}$ compared to the genome of necrotrophic plant pathogenic fungi
(Figure 1) [12,38]. Of the 86 proteins identified in the $U$. maydis secretome, we identified 23 CAZymes that target the plant cell wall. Of the most abundant proteins, we identified one GH10 xylanase and two GH51 and GH62 arabinofuranosidases. Interestingly, T. reesei genome has the smallest set of arabinofuranosidases of all of the plant cell wall-degrading ascomycetes. Thus, $U$. maydis hemicellulases may act in synergy with $T$. reesei enzymes to efficiently depolymerise wheat arabinoxylan, thereby facilitating cellulose access for the T. reesei cellulases. Another striking difference with the other fungal proteomes analysed, is the significant fraction of the $U$. maydis secretome (i.e. $8 \%$ of the total protein) of putative oxido-reductases that are potentially involved in the depolymerisation of lignocellulose. Two of the most abundant proteins identified corresponded to putative glucose-methanol-choline (GMC) oxidoreductases (Q4P967 and Q4P769), which are FAD flavoproteins with diverse catalytic activities and two others proteins are known as glyoxal oxidases (Q7Z866 and Q7Z867). Interestingly, $U$. maydis glyoxal oxidases have been experimentally shown to be essential for successful maize infection [39]. Although the role of fungal oxidoreductases in biomass deconstruction remains unclear, their presence suggest that, via the formation of highly reactive oxidants, they could participate in the depolymerisation of lignocellulose, as previously suggested for 
the wood-decaying fungus Postia placenta [40]. Indeed, glyoxal and glucose oxidases are known to generate $\mathrm{H}_{2} \mathrm{O}_{2}$ that is supposed to play a role in lesion formation and lesion expansion of plant cell wall in the infection mechanism of fungal pathogens [41]. As T. reesei is devoid of oxido-reductases, some of the putative $U$. maydis oxidases identified in its secretome are likely responsible for the observed increase in saccharification efficiency. Recent data from literature on the synergy between GH61 and oxido-reductases [42] might also explain the efficiency of $U$. maydis secretome in combination with $T$. reesei that contains a GH61 enzyme (EGIV). Recently, there has been growing interest in the potential of plant-pathogenic fungi to optimise the enzymatic treatment processes for the optimal hydrolysis of lignocellulosic biomass [43]. A recent large-scale screening using 156 ascomycetes revealed that the plant pathogens were more active than the non-pathogens on several lignocellulosic substrates [44]. U. maydis is a well characterised basidiomycete fungus that parasitises maize. It belongs to the smut fungi, which share a biotrophic mode of growth, i.e., they grow on the host plant without killing it. To our knowledge, the maize pathogenic basidiomycete $U$. maydis has never been tested for its hydrolysis potential of lignocellulosic biomass. The use of maize bran as an inducer is likely a key factor that contributed to the induction of the specific enzymes that target the plant cell walls of monocots (maize and wheat). The enzymes identified by the proteomic analysis of the secretome of $U$. maydis may facilitate access to cellulose and hemicellulose for the $T$. reesei CL847 enzymes, thereby explaining the increase in the glucose and xylose yields.

\section{Conclusions}

The discovery of fungal enzymes that display novel specificities is essential to efficiently breakdown lignocellulosic biomass for the production of biofuels and other high-value products. This post-genomic approach revealed the unexpected potential of $U$. maydis, which contained unique enzymatic equipment that significantly supplemented the $T$. reesei enzymatic cocktail. The putative $U$. maydis oxido-reductases could play a crucial role in improving the hydrolysis of plant cell walls. Future studies of the synergies between hydrolytic enzymes and oxido-reductases are necessary to give additional insights into the filamentous fungi enzymatic machineries.

\section{Methods}

\section{Annotation of Carbohydrate Active enZymes (CAZymes)}

To compare the sugar-cleaving capabilities of the fungi selected, we have listed the number of representatives of each of the glycoside hydrolases (GH) and polysaccharide lyases (PL) families (defined in the carbohydrate active enzyme database (CAZy database) http:// www.cazy.org; [9] and then performed a double clustering based on Bray-Curtis distances (i) between organisms according to their family distribution and (ii) between families according on their distribution pattern in the different genomes. Distances were computed using the multivariate analysis programme GINKGO [45]. The distance matrixes were computed using the Species Profiles Distance model and analysed by a hierarchical agglomerative clustering method.

\section{Fungal strains and enzymatic preparations}

The fungal strains used in this study were obtained from the CBS-KNAW (Centraalbureau voor Schimmelcultures, Utrecht, The Netherlands) and the FGSC (Fungal Genetics Stock Center, Kansas City, USA) fungal collections (Table 1). They were streaked and verified by ITS (Internal Transcribed Spacer) sequencing and maintained in the culture collection entitled "Centre International de Ressources Microbiennes", which is dedicated to filamentous fungi of biotechnological interest (CIRMCF; http://www.inra.fr/crb-cirm/), at the National Institute of Agricultural Research (INRA), Marseille, France. The strains were maintained on malt agar slants, using as MA2 (malt extract at $2 \% \mathrm{w} / \mathrm{v}$ ) medium for basidiomycetes and MYA2 (malt extract at $2 \% \mathrm{w} / \mathrm{v}$ and yeast extract at $0.1 \% \mathrm{w} / \mathrm{v}$ ) medium for ascomycetes and zygomycetes. The T. reesei CL847 secretome (E508 enzymatic cocktail) obtained from IFPEN (Rueil-Malmaison, France) was used as a reference enzymatic cocktail $[24,46]$.

\section{Culture conditions and secretome preparation}

Based on previous studies [22,23], the fungal cultures were grown in a liquid medium containing 15 g. $\mathrm{l}^{-1}$ (based on the dry matter) of the autoclaved maize bran fraction (provided by ARD, Pomacle, France) as a carbon source, $2.5 \mathrm{~g} . \mathrm{l}^{-1}$ of maltose as a starter, $1.842 \mathrm{~g} . \mathrm{l}^{-1}$ of diammonium tartrate as a nitrogen source, $0.5 \mathrm{~g}^{-1} \mathrm{l}^{-1}$ yeast

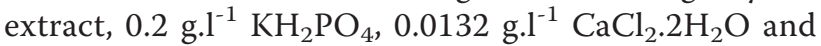
0.5 g. $^{-1} \mathrm{MgSO}_{4} \cdot 7 \mathrm{H}_{2} \mathrm{O}$. The sugar content $(\mathrm{w} / \mathrm{w})$ of the autoclaved maize bran fraction is $16.10 \%$ arabinose, $28.73 \%$ xylose, $0.17 \%$ mannose, $5.65 \%$ galactose and $22.06 \%$ glucose. Miniaturized fungal cultures were carried out in 16-well baffled plates as described in [47]. The cultures were inoculated with $2 \times 10^{5}$ spores. $\mathrm{ml}^{-1}$ for sporulating fungi, or with mycelial fragments generated using a Fastprep ${ }^{\circledR}-24$ (MP Biomedicals) set to $5 \mathrm{~m}$. $\mathrm{s}^{-1}$ for $40 \mathrm{~s}$, for non-sporulating fungi prior to incubation in 16 -well baffled plates at $30^{\circ} \mathrm{C}$ with orbital shaking at $140 \mathrm{rpm}$ (Infors HT, Switzerland).

All of the cultures were stopped at 7 days after inoculation. The cultures were stopped at 7 days after 
inoculation since (i) it is the mid-term growth for most of fungi (basidiomycetes and ascomycetes) in our conditions (16-well baffled plates) and (ii) extended growth led to evaporation of the culture medium. The culture broth (secretome) was harvested (total volume of 20 to $30 \mathrm{ml}$ ), filtered (using $0.2 \mu \mathrm{m}$ polyethersulfone membrane, Vivaspin, Sartorius), diafiltered and concentrated (Vivaspin with a $10 \mathrm{kDa}$ cut-off polyethersulfone membrane, Sartorius) in $50 \mathrm{mM}$ acetate solution buffer, $\mathrm{pH} 5$ to a final volume of $3 \mathrm{ml}$ and then stored in appropriate vials (1.2-ml tubes with septa in cluster plate, ABgene, Thermo scientific, USA) at $-20^{\circ} \mathrm{C}$ until use.

The total amount of protein was assessed using Bradford assays (Bio-Rad Protein Assay Dye Reagent Concentrate, Ivry, France) with a BSA standard that ranged from 0.2 to $1 \mathrm{mg} \cdot \mathrm{ml}^{-1}$.

\section{Saccharification assays on micronised lignocellulosic substrates}

The concentrated secretomes were tested for their ability to hydrolyse micronised WS (Triticum aestivum, Apache, France), which was prepared by G. Ghizzi and $\mathrm{X}$. Rouau as described in [25]. WS particles had an average size of $100 \mu \mathrm{m}$. A 1\% (w/v) WS suspension was prepared in $50 \mathrm{mM}$ acetate buffer, $\mathrm{pH} 5$, supplemented with $40 \mu \mathrm{g} \cdot \mathrm{ml}^{-1}$ of tetracycline as an antibiotic and 30 $\mu \mathrm{g} \cdot \mathrm{ml}^{-1}$ of cycloheximide as an antifungal agent. The resulting suspension was dispensed into 96-well plates by the Tecan Genesis Evo 200 robot (Tecan, Lyon, France) and the plates were frozen at $-20^{\circ} \mathrm{C}$ until needed.

The saccharification assay was performed using a high-throughput automated method that has been previously described [25] using a Tecan Genesis Evo 200 robot (Tecan). All of the appropriate blanks and controls reactions were performed as described in [25]. The initial step of wheat-straw hydrolysis was measured after 4 hours using normalized amount of protein $(20 \mu \mathrm{g}$ of T. reesei CL847 enzymatic cocktail and $10 \mu \mathrm{g}$ of each secretome). The control reaction was performed with 30 $\mu \mathrm{g}$ of T. reesei CL847 enzymatic cocktail. Saccharification was performed at $37^{\circ} \mathrm{C}$ with $8 \mathrm{~Hz}$ shaking. After 4 hours of incubation, the saccharification reactions were filtered and recovered; the reducing sugars were quantified using the DNS method and the glucose content was measured using a Glucose RTU kit (Biomérieux, Marcy l'Etoile, France) following the manufacturer's instructions. All of the reactions were performed independently at least six times.

To quantify the sugars released at the saccharification plateau (24 h for WS), $15 \mu \mathrm{l}$ of concentrated secretome (5 to $30 \mu \mathrm{g}$ total proteins) was added to the substrate plate either alone or in addition to $30 \mu \mathrm{g}$ of the $T$. reese $i$ CL847 enzymatic cocktail. The released reducing sugars were measured by DNS assay. The saccharification reactions were also analysed by high performance anion exchange chromatography (Dionex, Voisins-le-Bretonneux, France) and a CarboPac PA-1 column (Dionex) to quantify the amounts of glucose and xylose, as described in [24]. All of the reactions were independently performed at least in triplicate.

\section{Enzyme activity measurements}

$p$ NP-based chromogenic substrates and complex substrates were used to assay the enzymatic activities of the fungal secretomes. pGlc, pLac, pCel, pXyl, pAra, pGal, pMan and pAc were obtained from Sigma (SigmaAldrich, St.Louis, MO). For all $p$ NPs except for pAc, a 1 $\mathrm{mM} p \mathrm{NP}$ solutions was prepared in $50 \mathrm{mM}$ sodium acetate buffer $\mathrm{pH} 5$, and distributed into polystyrene 96well plates (IWAKI, Japan) at $100 \mu \mathrm{l}$ per well and one column per substrate. $p$ NP standards ranging from 0 to $0.2 \mathrm{mM}$ were then added to the plates. The plates were frozen at $-20^{\circ} \mathrm{C}$ until use. The assay was performed by adding appropriate dilutions of $20 \mu \mathrm{l}$ of the secretome to $p \mathrm{NP}$ plates that had been previously preincubated at $37^{\circ} \mathrm{C}$. The plates were sealed using a PlateLoc plate sealer (Velocity 11, Agilent) to prevent evaporation, and incubated at $37^{\circ} \mathrm{C}$ with shaking at $1000 \mathrm{rpm}$ (Mixmate, Eppendorf). After 30 minutes, the reaction was stopped by the addition of $130 \mu \mathrm{l}$ of $1 \mathrm{M} \mathrm{Na}_{2} \mathrm{CO}_{3}$ solution $\mathrm{pH}$ 11.5. The amount of $p \mathrm{NP}$ released was measured at 410 $\mathrm{nm}$ and quantified using a $p \mathrm{NP}$ standard curve ranging from 0 to $20 \mathrm{nmol}$. As pAc is unstable at room temperature in acetate buffer, $\mathrm{pH} 5$, the stock solution of pAc was prepared at $20 \mathrm{mM}$ in DMSO and diluted to 1 $\mathrm{mM}$ in $50 \mathrm{mM}$ sodium phosphate, $\mathrm{pH} 6.5$, just prior to use. We immediately added $15 \mu \mathrm{l}$ of the secretome, and the kinetics of hydrolysis were followed at $410 \mathrm{~nm}$ for one minute. One unit of enzyme was defined as $1 \mu \mathrm{mol}$ of $p$-nitrophenyl released per mg of enzyme per minute under our experimental conditions.

The complex substrates used in this study were carboxymethyl cellulose (CMC, Sigma), Avicel PH101 (Fluka), birchwood xylan (Sigma), low viscosity wheat arabinoxylan (Megazyme, Wicklow, Ireland), insoluble wheat arabinoxylan (Megazyme), insoluble ivory nut mannan (MAN, Megazyme), carob galactomannan (GMA, Megazyme), larch wood arabinogalactan (Megazyme) and sugar beet arabinan (Megazyme). A 1\% w/v suspension/solution was prepared in $50 \mathrm{mM}$ sodium acetate buffer, $\mathrm{pH} 5$, and distributed into 96-well plates at $100 \mu \mathrm{l}$ per well and one column per substrate. Glucose standards that ranged from 0 to $20 \mathrm{mM}$ were added to the plate. The plates were then frozen at $-20^{\circ} \mathrm{C}$ until use. The assay was performed by adding $20 \mu \mathrm{l}$ of the secretome (at three appropriate dilutions) to the previously thawed substrate plates. The plates were 
shaken and incubated at $37^{\circ} \mathrm{C}$ for one hour using the Tecan Genesis Evo 200 robot plate incubator (Tecan France, Lyon, France), and the reducing sugars were quantified using the automated DNS method, as described in [25]. One unit of enzyme was defined as 1 $\mu \mathrm{mol}$ of glucose equivalent released per mg of enzyme per minute under the assay conditions used here.

The global cellulase activity was determined on filter paper (Whatmann $\mathrm{n}^{\circ} 1$ ) using $6 \mathrm{~mm}$ diameter discs using a protocol adapted from [48]. Vials containing one filter paper disc in $100 \mu \mathrm{l}$ of $50 \mathrm{mM}$ sodium acetate buffer, $\mathrm{pH} 5$, and $50 \mu \mathrm{l}$ of the secretome were incubated for 2 hours at $50^{\circ} \mathrm{C}$. All of the assays were performed in triplicate. After incubation, the reducing sugars were quantified using the automated DNS method [25] with glucose standards that ranged from 0.2 to $20 \mathrm{mM}$. One unit of enzyme was defined as $1 \mu \mathrm{mol}$ of glucose equivalent released per $\mathrm{mg}$ of enzyme per minute under our experimental conditions.

Data from the activities measured in all the secretomes except $T$. reesei CL847 were ordered and grouped using the same clustering method as described for the genome analysis of CAZymes.

\section{Identification of proteins by LC-MS/MS analysis}

Proteins from the diafiltered supernatants of $A$. niger, $A$. nidulans, $U$. maydis and $T$. reesei CL847 $(25 \mu \mathrm{g})$ were separated by one-dimensional (1D) electrophoresis (Precast Tris-Glycine 12\% SDS-PAGE gels, BioRad) and stained with Coomassie blue (BioRad). Each 1D electrophoresis lane was cut into 24 gel fragments $(2 \mathrm{~mm}$ in width) and protein identification was performed using the PAPPSO platform facilities (http://pappso.inra.fr). In-gel digestion was carried out with the Progest system (Genomic Solution) according to a standard trypsinolysis protocol. Gel pieces were first washed twice with $10 \%(\mathrm{v} / \mathrm{v})$ acetic acid followed by a wash with $40 \%(\mathrm{v} / \mathrm{v})$ ethanol in water and then with acetonitrile. They were then further washed with $25 \mathrm{mM} \mathrm{NH}_{4} \mathrm{CO}_{3}$ and dehydrated in acetonitrile (two alternating cycles). Digestion was performed for 6 hours at $37^{\circ} \mathrm{C}$ with $125 \mathrm{ng}$ of modified trypsin (Promega) dissolved in $20 \%(\mathrm{v} / \mathrm{v})$ methanol in $20 \mathrm{mM} \mathrm{NH} \mathrm{CO}_{3}$. The tryptic peptides were first extracted with $50 \%(\mathrm{v} / \mathrm{v})$ acetonitrile and $0.5 \%$ trifluoroacetic acid in water and then with pure acetonitrile. The two peptide extracts were pooled, dried in a vacuum speed concentrator and suspended in $25 \mu \mathrm{l}$ of $2 \%(\mathrm{v} / \mathrm{v})$ acetonitrile and $0.08 \%(\mathrm{v} / \mathrm{v})$ trifluoroacetic acid in water.

LC-MS/MS analysis was performed on an Ultimate 3000 LC system (Dionex) connected to an LTQ-Orbitrap Discovery mass spectrometer (Thermo Fisher, USA) using a nanoelectrospray ion source. After $4 \mathrm{~min}$, the precolumn was connected to the separating nanocolumn Pepmap C18 $(0.075 \times 15 \mathrm{~cm}, 100 \AA, 3 \mu \mathrm{m})$ and the linear gradient was started from 2 to $36 \%$ of buffer B ( $80 \%$ acetonitrile and $0.1 \%$ formic acid) in buffer $\mathrm{A}$ ( $2 \%$ acetonitrile and $0.1 \%$ formic acid) at $300 \mathrm{nl} \cdot \mathrm{min}^{-1}$ for $50 \mathrm{~min}$. The doubly and triply charged precursor ions were subjected to MS/MS fragmentation with a 1min exclusion window and classical peptide fragmentation parameters $(\mathrm{Qz}=0.22$, activation time $=50 \mathrm{~ms}$, collision energy $=35 \%)$.

The raw mass data were first converted to the mzXML format with the ReAdW software (http://tools. proteomecenter.org/software.php). Protein identification was performed by querying the MS/MS data against the corresponding protein databases (UniProtKB, 2009.06.08) along with an in-house contaminant database, using the X!Tandem software (X!Tandem Tornado 2008.02.01.3, http://www.thegpm.org) with the following parameters: one missed trypsin cleavage, alkylation of cysteine and conditional oxidation of methionine precursor and fragment ion set to $10 \mathrm{ppm}$ and $0.5 \mathrm{Da}$, respectively. A refined search was added with similar parameters, except that the semi-tryptic peptides and the possibly $\mathrm{N}$-terminal acetylated proteins were included. All the peptides that matched with an E-value lower than 0.05 were parsed with an in-house programme (http://http:/PAPPSO.inra.fr/bioinformatique. html). Proteins identified by at least two unique peptides and a log (E-value) lower than 1.E-8 were considered to be validated. A list of proteins and peptides with masses and $\log$ (E-value) is provided for T. reesei, A. niger, A. nidulans and $U$. maydis proteomes in additional files 3 , 4, 5 and 6 (Tables S3, S4, S5, S6), respectively.

\section{Additional material}

Additional file 1: Activity profiling of fungal secretomes. The file
contains a table with enzymatic activities (mU/mg) that were obtained
using pNP-based substrates and complex substrates as described in
materials and methods. Values are means of triplicate independent
measures.
Additional file 2: List of proteins confidently identified in the $T$.
reesei CL847 enzymatic cocktail and the secretome of A. niger, $A$.
nidulans and $U$. maydis using 1D LC-MS/MS analyses. The file
contains an Excel table that includes SDS-Page of the T. reesei CL847
enzymatic cocktail and the secretome of A. niger, A. nidulans and U.
maydis and a list of the proteins that have been confidently identified in
the four samples using 1D LC-MS/MS analyses and annotation of
putative function. For CAZymes (GH and PL) and CBM, families are
indicated.
Additional file 3: Detailed list of the mass data of peptides
identified in the $T$. reesei CL847 enzymatic cocktail using 1D LC-MS/
MS analyses. The file contains an Excel table with data of peptides
identified
Additional file 4: Detailed list of the mass data of peptides
identified in the $A$. niger secretome using 1D LC-MS/MS analyses.
The file contains an Excel table with data of peptides identified
Additional file 5: Detailed list of the mass data of peptides
identified in the A. nidulans secretome using 1D LC-MS/MS
analyses. The file contains an Excel table with data of peptides identified


Additional file 6: Detailed list of the mass data of peptides identified in the $U$. maydis secretome using 1D LC-MS/MS analyses.

The file contains an Excel table with data of peptides identified

\section{List of abbreviations}

AVI: Avicel; AGA: arabinogalactan; ARB: arabinan; BRX: birchwood xylan; CAZy: Carbohydrate Active enZyme database; CAZyme: carbohydrate-active enzyme; CBM: carbohydrate binding module; CMC: carboxy-methyl cellulose; FP: filter paper; GH: glycosyl hydrolase; GMA: galactomannan; IAX: insoluble arabinoxylan; LC-MS/MS: liquid chromatography-tandem mass spectrometry; MAN: ivory nut mannan; pAc: pNP-acetate; pAra: $p N P$-a-L-arabinofuranoside; pCel: $p$ NP- $\beta$-D-cellobioside; pGal: pNP- $-\mathrm{D}$-galactopyranoside; pGlc: $p N P-\beta-D-$ glucopyranoside; PL: polysaccharide lyases; pLac: $p$ NP- $\beta$-D-lactobioside;

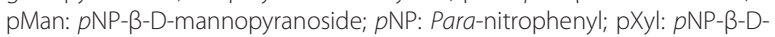
xylopyranoside; SAX: soluble wheat arabinoxylan; WS: wheat straw.

\section{Acknowledgements}

This study was funded by the French National Research Agency (ANR, program E-TRICEL ANR-07-BIOE-006). We thank X. Rouau and G. Ghizzi for the preparation of micronized wheat straw and C. Rancurel for automated CAZy annotation of proteomes.

\section{Author details}

${ }^{1}$ INRA, UMR1163 BCF, 13288 Marseille, France. ${ }^{2}$ INRA, UMR1163 CIRM-CF, 13288 Marseille, France. ${ }^{3}$ INRA, UMR1319 Micalis, PAPPSO, 78352 Jouy-enJosas, France. ${ }^{4}$ Aix-Marseille Universités, 13288 Marseille, France. ${ }^{5}$ CNRS, UMR6098 AFMB, 13288 Marseille, France.

\section{Authors' contributions}

MC carried out fungal cultures, enzyme and saccharification assays and helped to draft the manuscript. $\mathrm{CO}, \mathrm{DN}$ and $\mathrm{MH}$ helped to carry out experimental work. DC performed LC-MS/MS analyses and DN participated to the annotation of proteomes. DN, AF, LLM, BH, PMC and JGB participated in the design of the study. PMC and BH performed comparative genomic analysis and annotation of proteome. JGB and PMC conceived the study and coordinated and supervised the analysis. JGB drafted and submitted the manuscript. All authors read and approved the final manuscript.

\section{Competing interests}

The authors declare that they have no competing interests.

Received: 3 August 2011 Accepted: 2 February 2012

Published: 2 February 2012

\section{References}

1. Margeot A, Hahn-Hagerdal B, Edlund M, Slade R, Monot F: New improvements for lignocellulosic ethanol. Curr Opin Biotechnol 2009, 20:1-9.

2. Foust TD, Ibsen KN, Dayton DC, Hess JR, Kenney KE: The biorefinery. In Biomass Recalcitrance: Deconstructing the Plant Cell Wall for Bioenergy.. 1 edition. Edited by: Himmel ME. United Kingdom: Blackwell Publishing Ltd; 2008:7-37.

3. Sánchez C: Lignocellulosic residues: biodegradation and bioconversion by fungi. Biotechnol Adv 2009, 27(2):185-194.

4. Chundawat SP, Beckham GT, Himmel ME, Dale BE: Deconstruction of lignocellulosic biomass to fuels and chemicals. Annu Rev Chem Biomol Eng 2011, 2:121-145.

5. Lundell TK, Mäkelä MR, Hildén K: Lignin-modifying enzymes in filamentous basidiomycetes - ecological, functional and phylogenetic review. J Basic Microbiol 2010, 50(1):5-20.

6. Martinez D, Larrondo LF, Putnam N, Gelpke MD, Huang K, Chapman J, Helfenbein KG, Ramaiya P, Detter JC, Larimer F, Coutinho PM, Henrissat B, Berka R, Cullen D, Rokhsar D: Genome sequence of the lignocellulose degrading fungus Phanerochaete chrysosporium strain RP78. Nat Biotechnol 2004, 22(6):695-700.

7. Ravalason $\mathrm{H}$, Jan $\mathrm{G}$, Mollé $\mathrm{D}$, Pasco M, Coutinho PM, Lapierre C, Pollet $B$, Bertaud F, Petit-Conil M, Grisel S, Sigoillot JC, Asther M, Herpoël-Gimbert l:
Secretome analysis of Phanerochaete chrysosporium strain CIRM-BRFM41 grown on softwood. Appl Microbiol Biotechnol 2008, 80(4):719-733.

8. Martinez D, Berka RM, Henrissat B, Saloheimo M, Arvas M, Baker SE, Chapman J, Chertkov O, Coutinho PM, Cullen D, Danchin EG, Grigoriev IV, Harris P, Jackson M, Kubicek CP, Han CS, Ho I, Larrondo LF, de Leon AL, Magnuson JK, Merino S, Misra M, Nelson B, Putnam N, Robbertse B, Salamov AA, Schmoll M, Terry A, Thayer N, Westerholm-Parvinen A, Schoch CL, Yao J, Barabote R, Nelson MA, Detter C, Bruce D, Kuske CR, Xie G, Richardson P, Rokhsar DS, Lucas SM, Rubin EM, Dunn-Coleman N, Ward M, Brettin TS: Genome sequencing and analysis of the biomassdegrading fungus Trichoderma reesei (syn. Hypocrea jecorina). Nat Biotechnol 2008, 26(5):553-560.

9. Cantarel BL, Coutinho PM, Rancurel C, Bernard T, Lombard V, Henrissat B: The Carbohydrate-Active EnZymes database (CAZy): an expert resource for glycogenomics. Nucleic Acids Res 2009, 37:233-238.

10. Kubicek CP, Herrera-Estrella A, Seidl-Seiboth V, Martinez DA, Druzhinina IS, Thon M, Zeilinger S, Casas-Flores S, Horwitz BA, Mukherjee PK, Mukherjee M, Kredics L, Alcaraz LD, Aerts A, Antal Z, Atanasova L, Cervantes-Badillo MG, Challacombe J, Chertkov O, McCluskey K, Coulpier F, Deshpande N, von Döhren H, Ebbole DJ, Esquivel-Naranjo EU, Fekete E, Flipphi M, Glaser F, Gómez-Rodríguez EY, Gruber S, Han C, Henrissat B, Hermosa R, Hernández-Oñate M, Karaffa L, Kosti I, Le Crom S, Lindquist E, Lucas S, Lübeck M, Lübeck PS, Margeot A, Metz B, Misra M, Nevalainen H, Omann M, Packer N, Perrone G, Uresti-Rivera EE, Salamov A, Schmoll M, Seiboth B, Shapiro H, Sukno S, Tamayo-Ramos JA, Tisch D, Wiest A, Wilkinson HH, Zhang M, Coutinho PM, Kenerley CM, Monte E, Baker SE, Grigoriev IV: Comparative genome sequence analysis underscores mycoparasitism as the ancestral life style of Trichoderma. Genome Biol 2011, 12(4):R40.

11. Cuomo CA, Güldener U, Xu JR, Trail F, Turgeon BG, Di Pietro A, Walton JD, Ma L, Baker SE, Rep M, Adam G, Antoniw J, Baldwin T, Calvo S, Chang YL, Decaprio D, Gale LR, Gnerre S, Goswami RS, Hammond-Kosack K, Harris ${ }_{\text {, }}$ Hilburn K, Kennell JC, Kroken S, Magnuson JK, Mannhaupt G, Mauceli E, Mewes HW, Mitterbauer R, Muehlbauer G, Münsterkötter M, Nelson D, O'donnell K, Ouellet T, Qi W, Quesneville H, Roncero MI, Seong KY, Tetko IV, Urban M, Waalwijk C, Ward TJ, Yao J, Birren BW, Kistler HC: The Fusarium graminearum genome reveals a link between localized polymorphism and pathogen specialization. Science 2007, 317(5843):1400-1402.

12. Kämper J, Kahmann R, Bölker M, Ma LJ, Brefort T, Saville BJ, Banuett F, Kronstad JW, Gold SE, Müller O, Perlin MH, Wösten HA, de Vries R, RuizHerrera J, Reynaga-Peña CG, Snetselaar K, McCann M, Pérez-Martín J, Feldbrügge M, Basse CW, Steinberg G, Ibeas Jl, Holloman W, Guzman P, Farman M, Stajich JE, Sentandreu R, González-Prieto JM, Kennell JC, Molina L, Schirawski J, Mendoza-Mendoza A, Greilinger D, Münch K, Rössel N, Scherer M, Vranes M, Ladendorf O, Vincon V, Fuchs U, Sandrock B, Meng S, Ho EC, Cahill MJ, Boyce KJ, Klose J, Klosterman SJ, Deelstra HJ, Ortiz-Castellanos L, Li W, Sanchez-Alonso P, Schreier PH, Häuser-Hahn I, Vaupel M, Koopmann E, Friedrich G, Voss H, Schlüter T, Margolis J, Platt D, Swimmer C, Gnirke A, Chen F, Vysotskaia V, Mannhaupt G, Güldener U, Münsterkötter M, Haase D, Oesterheld M, Mewes HW, Mauceli EW, DeCaprio D, Wade CM, Butler J, Young S, Jaffe DB, Calvo S, Nusbaum C, Galagan J, Birren BW: Insights from the genome of the biotrophic fungal plant pathogen Ustilago maydis. Nature 2006, 444(7115):97-101.

13. Galagan JE, Calvo SE, Borkovich KA, Selker EU, Read ND, Jaffe D, FitzHugh W, Ma L, Smirnov S, Purcell S, Rehman B, Elkins T, Engels R, Wang S, Nielsen CB, Butler J, Endrizzi M, Qui D, lanakiev P, Bell-Pedersen D, Nelson MA, Werner-Washburne M, Selitrennikoff CP, Kinsey JA, Braun EL, Zelter A, Schulte U, Kothe GO, Jedd G, Mewes W, Staben C, Marcotte E, Greenberg D, Roy A, Foley K, Naylor J, Stange-Thomann N, Barrett R, Gnerre S, Kamal M, Kamvysselis M, Mauceli E, Bielke C, Rudd S, Frishman D, Krystofova S, Rasmussen C, Metzenberg RL, Perkins DD, Kroken S, Cogoni C, Macino G, Catcheside D, Li W, Pratt RJ, Osmani SA, DeSouza CP, Glass L, Orbach MJ, Berglund JA, Voelker R, Yarden O, Plamann M, Seiler S, Dunlap J, Radford A, Aramayo R, Natvig DO, Alex LA, Mannhaupt G, Ebbole DJ, Freitag M, Paulsen I, Sachs MS, Lander ES, Nusbaum C, Birren B: The genome sequence of the filamentous fungus Neurospora crassa. Nature 2003, 422(6934):859-868.

14. Coleman JJ, Rounsley SD, Rodriguez-Carres M, Kuo A, Wasmann CC, Grimwood J, Schmutz J, Taga M, White GJ, Zhou S, Schwartz DC, Freitag M, Ma L, Danchin EG, Henrissat B, Coutinho PM, Nelson DR, Straney D, Napoli CA, Barker BM, Gribskov M, Rep M, Kroken S, Molnár I, Rensing C, 
Kennell JC, Zamora J, Farman ML, Selker EU, Salamov A, Shapiro H, Pangilinan J, Lindquist E, Lamers C, Grigoriev IV, Geiser DM, Covert SF, Temporini E, Vanetten HD: The genome of Nectria haematococca: contribution of supernumerary chromosomes to gene expansion. PLoS Genet 2009, 5(8): 1000618

15. Galagan JE, Calvo SE, Cuomo C, Ma LJ, Wortman JR, Batzoglou S, Lee SI, Baștürkmen M, Spevak CC, Clutterbuck J, Kapitonov V, Jurka J, Scazzocchio C, Farman M, Butler J, Purcell S, Harris S, Braus GH, Draht O, Busch S, D'Enfert C, Bouchier C, Goldman GH, Bell-Pedersen D, GriffithsJones S, Doonan JH, YU J, Vienken K, Pain A, Freitag M, Selker EU, Archer DB, Peñalva MA, Oakley BR, Momany M, Tanaka T, Kumagai T, Asai K, Machida M, Nierman WC, Denning DW, Caddick M, Hynes M, Paoletti M, Fischer R, Miller B, Dyer P, Sachs MS, Osmani SA, Birren BW: Sequencing of Aspergillus nidulans and comparative analysis with $A$. fumigatus and $A$. oryzae. Nature 2005, 438(7071):1105-1115

16. Nierman WC, Pain A, Anderson MJ, Wortman JR, Kim HS, Arroyo J, Berriman M, Abe K, Archer DB, Bermejo C, Bennett J, Bowyer P, Chen D, Collins M, Coulsen R, Davies R, Dyer PS, Farman M, Fedorova N, Fedorova N, Feldblyum TV, Fischer R, Fosker N, Fraser A, García JL, García MJ, Goble A, Goldman GH, Gomi K, Griffith-Jones S, Gwilliam R, Haas B, Haas H, Harris D, Horiuchi H, Huang J, Humphray S, Jiménez J, Keller N, Khouri H, Kitamoto K, Kobayashi T, Konzack S, Kulkarni R, Kumagai T, Lafon A, Latgé JP, Li W, Lord A, Lu C, Majoros WH, May GS, Miller BL, Mohamoud Y, Molina M, Monod M, Mouyna I, Mulligan S, Murphy L, O'Neil S, Paulsen I, Peñalva MA, Pertea M, Price C, Pritchard BL, Quail MA, Rabbinowitsch E, Rawlins N, Rajandream MA, Reichard U, Renauld H, Robson GD, Rodriguez de Córdoba S, Rodríguez-Peña JM, Ronning CM, Rutter S, Salzberg SL, Sanchez M, Sánchez-Ferrero JC, Saunders D, Seeger K, Squares R, Squares S, Takeuchi M, Tekaia F, Turner G, Vazquez de Aldana CR, Weidman J, White O, Woodward J, Yu JH, Fraser C, Galagan JE, Asai K, Machida M, Hall N, Barrell B, Denning DW: Genomic sequence of the pathogenic and allergenic filamentous fungus Aspergillus fumigatus. Nature 2005, 438(7071):1151-1156.

17. Machida M, Asai K, Sano M, Tanaka T, Kumagai T, Terai G, Kusumoto K, Arima T, Akita O, Kashiwagi Y, Abe K, Gomi K, Horiuchi H, Kitamoto K, Kobayashi T, Takeuchi M, Denning DW, Galagan JE, Nierman WC, Yu J, Archer DB, Bennett JW, Bhatnagar D, Cleveland TE, Fedorova ND, Gotoh O, Horikawa H, Hosoyama A, Ichinomiya M, Igarashi R, Iwashita K, Juvvadi PR, Kato M, Kato Y, Kin T, Kokubun A, Maeda H, Maeyama N, Maruyama J, Nagasaki H, Nakajima T, Oda K, Okada K, Paulsen I, Sakamoto K, Sawano T, Takahashi M, Takase K, Terabayashi Y, Wortman JR, Yamada O, Yamagata Y, Anazawa H, Hata Y, Koide Y, Komori T, Koyama Y, Minetoki T, Suharnan S, Tanaka A, Isono K, Kuhara S, Ogasawara N, Kikuchi H: Genome sequencing and analysis of Aspergillus oryzae. Nature 2005, 438(7071):1157-1161.

18. Pel HJ, de Winde JH, Archer DB, Dyer PS, Hofmann G, Schaap PJ, Turner G, de Vries RP, Albang R, Albermann K, Andersen MR, Bendtsen JD, Benen JA, van den Berg M, Breestraat S, Caddick MX, Contreras R, Cornell M, Coutinho PM, Danchin EG, Debets AJ, Dekker P, van Dijck PW, van Dijk A, Dijkhuizen L, Driessen AJ, d'Enfert C, Geysens S, Goosen C, Groot GS, de Groot PW, Guillemette T, Henrissat B, Herweijer M, van den Hombergh JP, van den Hondel CA, van der Heijden RT, van der Kaaij RM, Klis FM, Kools HJ, Kubicek CP, van Kuyk PA, Lauber J, Lu X, van der Maarel MJ, Meulenberg R, Menke H, Mortimer MA, Nielsen J, Oliver SG, Olsthoorn M, Pal K, van Peij NN, Ram AF, Rinas U, Roubos JA, Sagt CM, Schmoll M, Sun J, Ussery D, Varga J, Vervecken W, van de Vondervoort PJ, Wedler $H$, Wösten HA, Zeng AP, van Ooyen AJ, Visser J, Stam H: Genome sequencing and analysis of the versatile cell factory Aspergillus niger CBS 513.88. Nat Biotechnol 2007, 25(2):221-231.

19. Andersen MR, Nielsen J: Current status of systems biology in Aspergilli. Fungal Genet Biol 2009, 46(Suppl 1):180-190.

20. Martin F, Cullen D, Hibbett D, Pisabarro A, Spatafora JW, Baker SE, Grigoriev IV: Sequencing the fungal tree of life. New Phytol 2011, 190(4):818-821.

21. Kim Y, Nandakumar MP, Marten MR: The state of proteome profiling in the fungal genus Aspergillus. Brief Funct Genomic Proteomic 2008, 7(2):87-94.

22. Bonnin E, Brunel M, Gouy $Y$, Lesage-Meessen L, Asther M, Thibault JF: Aspergillus niger I-1472 and Pycnoporus cinnabarinus MUCL39533, selected for the biotransformation of ferulic acid to vanillin, are also able to produce cell wall polysaccharide-degrading enzymes and feruloyl esterases. Enzyme Microb Technol 2001, 28:70-80.
23. Lesage-Meessen L, Lomascolo A, Bonnin E, Thibault JF, Buleon A, Roller M, Asther Mi, Record E, Colonna Ceccaldi B, Asther M: A biotechnological process involving filamentous fungi to produce natural crystalline vanillin from maize bran. Appl Biochem Biotechnol 2002, 102-103(16):141-153.

24. Couturier M, Haon M, Coutinho PM, Henrissat B, Lesage-Meessen L, Berrin JG: Podospora anserina hemicellulases potentiate the Trichoderma reesei secretome for saccharification of lignocellulosic biomass. Appl Environ Microbiol 2011, 77(1):237-246.

25. Navarro D, Couturier M, da Silva GG, Berrin JG, Rouau X, Asther M, Bignon C: Automated assay for screening the enzymatic release of reducing sugars from micronized biomass. Microb Cell Fact 2010, 9:58.

26. Battaglia E, Benoit I, van den Brink J, Wiebenga A, Coutinho PM, Henrissat B, de Vries RP: Carbohydrate-active enzymes from the zygomycete fungus Rhizopus oryzae: a highly specialized approach to carbohydrate degradation depicted at genome level. BMC Genomics 2011, 12:38

27. Kabel MA, van der Maarel MJ, Klip G, Voragen AG, Schols HA: Standard assays do not predict the efficiency of commercial cellulase preparations towards plant materials. Biotechnol Bioeng 2006, 93(1):56-63.

28. Vanden Wymelenberg A, Minges $P$, Sabat $G$, Martinez D, Aerts A, Salamov A, Grigoriev I, Shapiro H, Putnam N, Belinky P, Dosoretz C, Gaskell J, Kersten P, Cullen D: Computational analysis of the Phanerochaete chrysosporium v2.0 genome database and mass spectrometry identification of peptides in ligninolytic cultures reveal complex mixtures of secreted proteins. Fungal Genet Biol 2006, 43(5):343-356.

29. Vanden Wymelenberg A, Gaskell J, Mozuch M, Sabat G, Ralph J, Skyba O, Mansfield SD, Blanchette RA, Martinez D, Grigoriev I, Kersten PJ, Cullen D: Comparative transcriptome and secretome analysis of wood decay fungi Postia placenta and Phanerochaete chrysosporium. Appl Environ Microbiol 2010, 76(11):3599-3610.

30. Harris PV, Welner D, MCFarland KC, Re E, Navarro Poulsen JC, Brown K, Salbo R, Ding H, Vlasenko E, Merino S, Xu F, Cherry J, Larsen S, Lo Leggio L: Stimulation of lignocellulosic biomass hydrolysis by proteins of glycoside hydrolase family 61: structure and function of a large, enigmatic family. Biochemistry 2010, 49(15):3305-3316.

31. Quinlan RJ, Sweeney MD, Lo Leggio L, Otten H, Poulsen JC, Johansen KS, Krogh KB, Jørgensen Cl, Tovborg M, Anthonsen A, Tryfona T, Walter CP, Dupree P, Xu F, Davies GJ, Walton PH: Insights into the oxidative degradation of cellulose by a copper metalloenzyme that exploits biomass components. Proc Natl Acad Sci USA 2011, 108(37):15079-15084.

32. Paper JM, Scott-Craig JS, Adhikari ND, Cuomo CA, Walton JD: Comparative proteomics of extracellular proteins in vitro and in planta from the pathogenic fungus Fusarium graminearum. Proteomics 2007, 7(17):3171-3183.

33. Phalip V, Delalande F, Carapito C, Goubet F, Hatsch D, Leize-Wagner E, Dupree P, Dorsselaer AV, Jeltsch JM: Diversity of the exoproteome of Fusarium graminearum grown on plant cell wall. Curr Genet 2005, 48(6):366-379.

34. Tsang A, Butler G, Powlowski J, Panisko EA, Baker SE: Analytical and computational approaches to define the Aspergillus niger secretome. Fungal Genet Biol 2009, 46(Suppl 1):153-160.

35. Herpoël-Gimbert I, Margeot A, Dolla A, Jan G, Mollé D, Lignon S, Mathis $H$, Sigoillot JC, Monot F, Asther M: Comparative secretome analyses of two Trichoderma reesei RUT-C30 and CL847 hypersecretory strains. Biotechnol Biofuels 2008, 1(1):18.

36. Battaglia E, Hansen SF, Leendertse A, Madrid S, Mulder H, Nikolaev I, de Vries RP: Regulation of pentose utilisation by $A r a R$, but not $X \operatorname{In} R$, differs in Aspergillus nidulans and Aspergillus niger. Appl Microbiol Biotechnol 2011, 91(2):387-397.

37. Coutinho PM, Andersen MR, Kolenova K, vanKuyk PA, Benoit I, Gruben BS, Trejo-Aguilar B, Visser H, van Solingen P, Pakula T, Seiboth B, Battaglia E, Aguilar-Osorio G, de Jong JF, Ohm RA, Aguilar M, Henrissat B, Nielsen J, Stålbrand $\mathrm{H}$, de Vries RP: Post-genomic insights into the plant polysaccharide degradation potential of Aspergillus nidulans and comparison to Aspergillus niger and Aspergillus oryzae. Fungal Genet Biol 2009, 46(Suppl 1):161-169.

38. Mueller O, Kahmann R, Aguilar G, Trejo-Aguilar B, Wu A, de Vries RP: The secretome of the maize pathogen Ustilago maydis. Fungal Genet Biol 2008, 45(Suppl 1):63-70. 
39. Leuthner $B$, Aichinger $C$, Oehmen $E$, Koopmann $E$, Müller $O$, Müller $P$, Kahmann $\mathrm{R}$, Bölker $\mathrm{M}$, Schreier $\mathrm{PH}$ : $\mathrm{A} \mathrm{H}_{2} \mathrm{O}_{2}$-producing glyoxal oxidase is required for filamentous growth and pathogenicity in Ustilago maydis. Mol Genet Genomics 2005, 272(6):639-650.

40. Martinez D, Challacombe J, Morgenstern I, Hibbett D, Schmoll M, Kubicek CP, Ferreira P, Ruiz-Duenas FJ, Martinez AT, Kersten P, Hammel KE, Vanden Wymelenberg A, Gaskell J, Lindquist E, Sabat G, Bondurant SS,

Larrondo LF, Canessa P, Vicuna R, Yadav J, Doddapaneni H, Subramanian V, Pisabarro AG, Lavín JL, Oguiza JA, Master E, Henrissat B, Coutinho PM, Harris P, Magnuson JK, Baker SE, Bruno K, Kenealy W, Hoegger PJ, Kües U, Ramaiya P, Lucas S, Salamov A, Shapiro H, Tu H, Chee CL, Misra M, Xie G, Teter S, Yaver D, James T, Mokrejs M, Pospisek M, Grigoriev IV, Brettin T, Rokhsar D, Berka R, Cullen D: Genome, transcriptome, and secretome analysis of wood decay fungus Postia placenta supports unique mechanisms of lignocellulose conversion. Proc Natl Acad Sci USA 2009, 106(6):1954-1959

41. Gorvin EM, Levine A: The hypersensitive response facilitates plant infection by the necrotrophic pathogen Botrytis cinerea. Curr Biol 2000, 10(13):751-777.

42. Langston JA, Shaghasi T, Abbate E, Xu F, Vlasenko E, Sweeney MD: Oxidoreductive cellulose depolymerization by the enzymes cellobiose dehydrogenase and glycoside hydrolase 61. Appl Environ Microbiol 2011, 77(19):7007-7015.

43. Gibson DM, King BC, Hayes ML, Bergstrom GC: Plant pathogens as a source of diverse enzymes for lignocellulose digestion. Curr Opin Microbiol 2011, 14(3):264-270.

44. King BC, Waxman KD, Nenni NV, Walker LP, Bergstrom GC, Gibson DM: Arsenal of plant cell wall degrading enzymes reflects host preference among plant pathogenic fungi. Biotechnol Biofuels 2011, 16(4):4.

45. Bouxin G: Ginkgo, a multivariate analysis package. J Veget Sci 2005, 16:353-359.

46. Tabka MG, Herpoël-Gimbert I, Monod F, Asther M, Sigoillot JC: Enzymatic saccharification of wheat straw for bioethanol production by a combined cellulase xylanase and feruloyl esterase treatment. Enzyme Microb Technol 2006, 39:897-902.

47. Alberto F, Navarro D, de Vries RP, Asther M, Record E: Technical advance in fungal biotechnology: development of a miniaturized culture method and an automated high-throughput screening. Lett Appl Microbiol 2009, 49(2):278-282.

48. Ghose TK: Measurement of cellulase activities. Pure Appl Chem 1987, 59:257-268.

49. Saeed Al, Bhagabati NK, Braisted JC, Liang W, Sharov V, Howe EA, Li J, Thiagarajan M, White JA, Quackenbush J: TM4 microarray software suite. Methods Enzymol 2006, 411:134-193.

doi:10.1186/1471-2164-13-57

Cite this article as: Couturier et al:: Post-genomic analyses of fungal lignocellulosic biomass degradation reveal the unexpected potential of the plant pathogen Ustilago maydis. BMC Genomics 2012 13:57.

\section{Submit your next manuscript to BioMed Central and take full advantage of:}

- Convenient online submission

- Thorough peer review

- No space constraints or color figure charges

- Immediate publication on acceptance

- Inclusion in PubMed, CAS, Scopus and Google Scholar

- Research which is freely available for redistribution

Submit your manuscript at www.biomedcentral.com/submit
Biomed Central 